\title{
CHALLENGES IN INDUSTRIAL APPLICATIONS OF TECHNICAL LIGNINS
}

\author{
Alexey Vishtal* and Andrzej Kraslawski \\ The primary aim of modern biorefineries is the efficient conversion of \\ lignocellulosic materials into valuable products. Sugars and oils can be \\ converted into valuable chemicals, but processing of lignin is still a \\ challenge. A vast amount of lignin is incinerated to produce process \\ steam and energy, and only a very small part is used for the production \\ of value-added products. Technical lignins are isolated as by-streams in \\ lignocellulosic refineries, e.g., as kraft, soda, organosolv, and hydrolysis \\ lignins, as well as lignosulphonates. They have a modified structure and \\ contain impurities that are dependent on the processing method. The \\ structure and the composition of technical lignins restrict their \\ subsequent applications. This paper reviews limiting factors in utilization \\ of technical lignins. Four major classes of problems are identified, and \\ approaches to overcoming these problems are suggested.
}

Keywords: Lignin; Biorefinery; Structure; Reactivity; Purification; Recovery

Contact information: Lappeenranta University of Technology, Faculty of Technology, Laboratory of Systems Engineering, P.O. Box 20, 53581 Lappeenranta, Finland; * Corresponding author: alexey.vishtal@lut.fi

\section{INTRODUCTION}

Lignin is the second most abundant natural substance in the world after cellulose (Rastogi and Dwivedi 2007), and annually, around $5 \times 10^{6}$ metric tons of lignin is produced by industry (Mai et al. 2000). A major part of industrial lignin is incinerated for the production of process steam and energy (Mohan et al. 2006). However, the utilization of lignin as a fuel is not economically rational; the money equivalent of lignin used as fuel is $0.18 \mathrm{US} \$ / \mathrm{kg}$, while the approximate value of lignin used in chemical conversion can be as high as 1.08 US $\$ / \mathrm{kg}$ (Macfarlane et al. 2009). An economical assessment of chemical conversion technologies based on lignin feedstock is presented in Holladay et al. (2007). Despite its potential, lignin as a raw material for chemical conversion is underutilized by industry (El Mansouri and Salvadó 2006; Doherty et al. 2011).

Biorefining of natural feedstocks is a promising approach to promote broader use of lignin. The biorefinery concept is based on complex utilization of biomass-derived feedstocks, such as lignocellulosic materials, oil and sugar crops, and algae (Demibras 2009; Cherubini 2010). The three major components of lignocellulosic materials are: cellulose, hemicelluloses, and lignin (Sjöström 1982). Most biorefineries currently concentrate on the valorization of cellulose and hemicelluloses (FitzPatrick et al. 2010), a so-called sugar-based platform, while lignin is usually considered as a low-value residual (Cherubini et al. 2010; Doherty et al. 2011). Unlike sugars, which are released as uniform monomeric carbohydrates, lignin is delivered as a complex and polydisperse compound. 
This complex structure and the uncertain reactivity of lignin are the main factors limiting its wide-scale use in biorefineries.

The conversion of lignin into valuable products is one way to unleash lignin's potential. Technical lignins can be considered as a potentially interesting raw material, since they are produced in processes dealing with the treatment of lignocellulosic materials, and many technical lignins are readily available in large amounts (kraft lignin, lignosulphonates, and soda lignin). In contrast, hydrolysis, organosolv, and ionic liquid lignins constitute only a small part of potentially valuable lignins. They are produced in rather small amounts but may evolve into industrial-scale products (Gosselink et al. 2004). In some cases, the removal of lignin from the product streams of existing pulp mills is beneficial, as in the case of small non-wood mills, where it allows bottlenecks in the recovery boiler to be removed and provides a solution to some environmental problems (Gosselink et al. 2004).

Utilization of technical lignins in high-value-added applications is limited. There are several factors restricting the use of lignin, namely: a non-uniform structure, unique chemical reactivity, and the presence of various organic and inorganic impurities. Moreover, difficulties exist in the recovery of lignins from the product streams. The aim of this paper is to characterize the major challenges for chemical and biochemical conversion of technical lignins. The emphasis in this review is placed on the identification of the major factors restricting lignin utilization, as well as the evaluation of possible methods to approach existing problems. Special attention is paid to the structural features of each type of technical lignin.

\section{TECHNICAL LIGNINS}

Identification of problems related to the utilization of technical lignins requires indepth analysis of the structure, composition, and features of lignins. Since technical lignins originate from different sources and separation processes, they differ from each other to a significant extent, and, as a result, each technical lignin type needs to be considered individually.

\section{Kraft Lignin}

Kraft lignin is produced in the sulphate (kraft) cooking process. It constitutes about $85 \%$ of total world lignin production (Tejado et al. 2007). During cooking, around 90 to $95 \%$ of the lignin contained in the wood is dissolved in the aqueous solution of sodium hydroxide and sodium sulfide (Chakar and Ragauskas 2004). Lignin is degraded into fragments of different molecular weight, which are soluble in alkali solutions (Chakar and Ragauskas 2004). The lignin fragments contribute to the deep brown color of spent liquor from cooking (Betancur et al. 2009). Annually, around $63 \times 10^{4}$ tons of kraft lignin is produced. However, the major part of kraft lignin tends to be used only in low-added-value applications such as the production of process steam and energy (Mohan et al. 2006). Only around 100,000 tons are used in other products and applications (El Mansouri and Salvadó 2006). In modern pulp mills, incineration of black liquor produces a surplus of energy, allowing extraction of a part of dissolved lignin and its use 
for further conversion into valuable products (Jönsson et al. 2008; Jönsson and Wallberg 2009).

Kraft lignin has found many applications. However, most of them are lowtonnage or pilot-scale products. Examples of kraft lignin-based products are: carriers for fertilizers and pesticides (Ramirez et al. 1997; Zhang 2008), carbon fibers (Kubo et al. 1998; Kadla et al. 2002), blends with thermoplastic polymers (Cazaku et al. 2004; Gosselink et al. 2005), binders and resins (Alonso et al. 2004; Turunen et al. 2003; Tejado et al. 2007), ion-exchange resins (Zoumpoulakis and Simitzis 2001; Dizhbite et al. 1999), and activated carbons (Fierro et al. 2003; Carrott and Carrott 2007). In addition to these applications, kraft lignin can be used for production of low molecular weight compounds such as vanillin, hydroxylated aromatics, quinines, aldehydes, and aliphatic acids (Jöhnson et al. 2005; Holladey et al. 2007).

Kraft lignin contains several characteristic features distinguishing it from native lignin and other technical lignins. It contains an increased amount of phenolic hydroxyl groups due to extensive cleavage of $\beta$-aryl bonds during cooking. Moreover, some biphenyl and other condensed structures are formed as a result of the severe cooking conditions. Generally the amount of condensed structures increases with the duration of the cooking. The oxidative conditions during delignification can cause formation of quinine and catechol structures as well as increase the amount of carboxyl groups (Chakar and Ragauskas 2004). After cooking, kraft lignin has a high content of ash (up to 30\%). The ash is removed by washing or treatment with diluted sulphuric acid (El Mansouri and Salvado 2006), giving an ash content of washed lignin of around 1 to 5\%. The molecular weight of kraft lignin obtained from black liquor varies within the range 200 to 200,000 grams per mole (Morck et al. 1986; Niemelä 1990). Data on the chemical composition and structure of kraft lignin are presented in Table 1.

\section{Soda Lignin}

Soda lignin originates from soda or soda-anthraquinone pulping processes. Sodabased cooking methods are used mainly for cooking of annual crops such as flax, straws, bagasse, and, to some extent, hardwoods (Saake and Lehnen 2007; Gonzalez-Garcia et al. 2010; Rodriguez et al. 2010). The main difference in comparison to the kraft process is the sulphur-free medium of the cooking liquor (Gullischsen and Fogenholm 2000). The recovery of spent cooking liquor from pulping of non-woods is not without problems, because of the high content of silica. Separation of lignin is one alternative to improve the efficiency of these mills and also allows some environmental problems to be mitigated (Ghatak 2008).

Soda lignin has found application in areas such as the production of phenolic resins (Gosselink et al. 2004; Tejado et al. 2007), animal nutrition (Baurhoo et al. 2008), and dispersants (Nadif et al. 2002). These applications require high purity and biocompatibility; i.e., any toxic reaction in animals has to be avoided (Belgacem and Gandini 2008). According to Wormeyer et al. (2011), soda lignin is suitable for synthesis of polymers. The utilization of soda lignin is also possible for synthesis of low-molecular weight substances.

Soda lignin is sulphur-free, meaning that the chemical composition of soda lignin is closer to that of natural lignin in comparison with kraft lignin and lignosulphonates 
(Nadif et al. 2002; Wormeyer et al. 2011). Soda lignins from non-wood plants differ from wood lignins. They contain more p-hydroxyl units and carboxyl groups (Buranov and Mazza 2008; Wormeyer et al. 2011). The distinct character of non-wood lignins has been presented by Buranov and Mazza (2008) and Wormeyer et al. (2011). Other features of non-wood lignin are a high silicate and nitrogen contents (Buranov and Mazza 2008; Lora 2008; Wormeyer et al. 2011). The data on chemical composition and molecular weight of soda lignin are shown in Table 1.

\section{Lignosulphonates}

Lignosulphonates are water-soluble anionic polyelectrolytes that contain a large number of charged groups. Lignosulphonates are obtained as the by-product of sulphite cooking, in which delignification of wood is performed by means of $\mathrm{HSO}_{3}{ }^{-}$and $\mathrm{SO}_{3}{ }^{2-}$ ions (Fan and Zhan 2008; Belgacem and Gandini 2008). During this process, lignin is sulphonated, degraded, and solubilized. Lignosulphonates are produced in relatively large quantities, around 1 million tons per year as dry solids (El Mansouri and Salvadó 2006; Belgacem and Gandini 2008). The production of lignosulphonates has been commercialized by many companies; the major producer is Borregaard LignoTech, with a capacity of about 500,000 metric tons (Belgacem and Gandini 2008).

Lignosulphonates have a variety of functional groups: phenolic hydroxyl groups, carboxylic groups, and sulphur containing groups (Areskogh et al. 2010). The variety of functional groups and other structural features provide unique colloidal properties (Myrvold 2008; Areskogh et al. 2010; Areskogh and Henriksson 2011). These properties allow applications such as: stabilizers in colloidal suspensions, dispersing agents (Fagerholm et al. 1999), binders for drilling agents (Zhang and Yin 2002), detergents (Lora 2008), glues (Lora 2008), animal feeds (Lora 2008), particleboards (Jin et al. 2011), surfactants (Palmqvist et al. 2006), adhesives (Shulga et al. 2001; Alonso et al. 2004), and cement additives (Grierson et al. 2005; Ansari and Pawlik 2007).

Characteristic structural and chemical properties of lignosulphonates are: solubility in water, relatively high molecular weight, broad distribution of molecular weights, and quite high ash content (Shulga et al. 2005; Lora 2008). The degree of sulfonation of lignosulphonates is 0.4 to 0.5 per phenylpropanoid unit (Gellerstedt and Henriksson 2008). A comparison of lignosulphonates with other technical lignins is shown in Table 1.

\section{Organosolv Lignins}

In the organosolv pulping process, a mixture of organic solvent/solvents and water is used as a cooking medium (Gullischen and Fogelholm 2000). The most commonly used solvents are: acetic acid, formic acid, ethanol, and peroxiorganic acids (Xu et al. 2006). Some of these organosolv pulping processes have been commercially registered (FormicoFib, Alcell, Acetosolv, Organocell and ASAM) and realized at industrial scale (Gullischen and Fogelholm 2000; Xu et al. 2006; Wang et al. 2009). In the organosolv processes lignin is separated via solubilization. Solubilization makes it possible to obtain a less modified lignin. The homogeneity of organosolv lignin is higher than that of lignosulphonates or alkali lignins (Lora 1993; El Mansouri and Salvadó 2006). 
Organosolv lignin is used as a filler in the formulations of inks, varnishes and paints (Belgacem et al. 2003), and it can be used in the same applications as kraft and soda lignin. However, due to its low molecular weight, its utilization in adhesives and binders is rather limited.

The properties of organosolv lignins differ from other technical lignins. The major features are low molecular weight and high chemical purity. Organosolv lignins are hydrophobic and show very poor solubility in water (Lora and Glasser 2003). Organosolv pulping produces lignin of high quality, containing a lot of reactive side chains available for further chemical reactions (Meister 2002). The properties of organosolv lignins are given in Table 1.

\section{Hydrolysis Lignin}

Dilute acid hydrolysis of wood has been used on a large scale for the production of ethanol (Hol'kin 1989). However, this technology nowadays is somewhat out of date due to high water consumption and poor recovery rates (Hol'kin 1989; Iranmahboob 2002). Most biorefinery concepts offer advanced technologies for conversion of sugars contained in wood. These technologies include various pretreatments combined with subsequent enzymatic hydrolysis and fermentation (Chandra 2007). The dissolved sugars are used for fermentation, while the undissolved residual lignin is usually used as fuel (Hamenlinck et al. 2005).

Enzymatic hydrolysis lignin shows higher activity than lignosulphonates and kraft lignin and can be used in preparation of polymeric materials (Nakagame et al. 2011). Carrot et al. (2008) have reported that hydrolysis lignin contains a lot of condensed structures with higher molecular weight. Sazanov et al. (2009) have shown the applicability of hydrolysis lignin in graft copolymerization with acrilonitrile.

Hydrolysis lignins have high sorption ability and are difficult to dewater. These properties permit the utilization of hydrolysis lignins as a sorbent. Sorption properties of lignins have been discussed by Dizhbite et al. (1999), Baklanova et al. (2003), and Carrott and Carrott (2007). Hydrolysis lignins can be divided into two main subgroups: enzymatic hydrolysis lignin and acid hydrolysis lignin, according to the type of hydrolysis process. Acid hydrolysis can be realized using either organic (formic, acetic) or inorganic (sulphuric, hydrochloric) acids (Zhang et al. 2010). Hydrolysis lignins can also be distinguished by origin, i.e., softwood, hardwood, and non-wood. Some properties of hydrolysis lignin are given in Table 1.

\section{Ionic Liquid Lignins}

Ionic liquids have been described as "green" solvents, being comprised as organic salts that remain as liquids at relatively low temperatures (Muhammad et al. 2011). There is a growing interest in utilization of ionic liquids for the processing of biomass. Several ionic liquids have been found to be able to fractionate lignocellulosic materials (MäkiArvela et al. 2010; Muhammad et al. 2011; Olivier-Bourbigou et al. 2011), and some biorefinery concepts propose the use of ionic liquids (FitzPatrick et al. 2010). This approach seems quite promising. For instance, Tan et al. (2009) have reported dissolution of $93 \%$ of lignin contained in bagasse by the use of alkylbenzenesulfonate ionic liquid. Sun et al. (2009) have reported the use of ionic liquid in the dissolution of softwood and 
hardwood. The dissolution of lignin was $26.1 \%$ and $34.9 \%$ of the initial lignin in the softwood and hardwood lignin, respectively. Fasching et al. (2007) have developed a method for isolation of lignin from wood using a mixture of $\mathrm{N}$-methylimidizole and dimethylsulfoxide.

It should be noted that lignin obtained by fractionation with ionic liquids is not yet available on an industrial scale and it cannot be fully regarded as a technical lignin. However, due to recent successes in this area, it can be considered as a promising option. Lignin obtained with ionic liquids has similar properties to organosolv lignin and can be used in the same applications as soda and organosolv lignins. The ionic liquid medium allows the lignin to be exposed to various chemical reactions (Binder et al. 2009).

Lignin can be recovered from the ionic liquid by precipitation via addition of nonsolvents (water, acetonitrile), and the ionic liquid can be recycled (Argyropolous 2008; Muhammad et al. 2011). Information on the properties of ionic liquid lignin can be found in Table 1.

\section{Summary of the Chemical composition of Technical Lignins}

Technical lignins have diverse properties allowing for a broad range of applications. These applications require lignins with tailored properties: molecular weight, purity, homogeneity, and the presence of certain functional groups. The major chemical properties of technical lignins are shown in Table 1.

Table 1. Chemical Composition of the Technical Lignins*

\begin{tabular}{|c|c|c|c|c|c|c|}
\hline Parameter & $\mathrm{SL}^{* *}$ & $\mathrm{KL}^{* *}$ & $\mathrm{HL}^{* *}$ & $\mathrm{OSL}^{* *}$ & $\mathrm{LS}^{* *}$ & $\mathrm{ILL}^{* *}$ \\
\hline Ash, \% & $0.7-2.3$ & $0.5-3.0$ & $1.0-3.0$ & 1.7 & $4.0-8.0$ & $0.6-2.0$ \\
\hline $\begin{array}{l}\text { Moisture content; } \\
\quad \%\end{array}$ & $2.5-5.0$ & $3.0-6.0$ & $4.0-9.0$ & 7.5 & 5.8 & - \\
\hline Carbohydrates, $\%$ & $1.5-3.0$ & $1.0-2.3$ & $10.0-22.4$ & $1-3$ & - & 0.1 \\
\hline $\begin{array}{l}\text { Acid soluble } \\
\text { lignin, } \%\end{array}$ & $1.0-11$ & $1-4.9$ & 2.9 & 1.9 & - & - \\
\hline Nitrogen, $\%$ & $0.2-1.0$ & 0.05 & $0.5-1.4$ & $0-0.3$ & 0.02 & - \\
\hline Sulphur,\% & 0 & $1.0-3.0$ & $0-1.0$ & 0 & $3.5-8.0$ & 1.5 \\
\hline $\begin{array}{l}\text { Molecular weight, } \\
\qquad M_{w}\end{array}$ & $\begin{array}{l}1,000- \\
3,000 \text { (up } \\
\text { to } 15,000 \text { ) }\end{array}$ & $\begin{array}{l}1,500- \\
5,000 \text { (up } \\
\text { to } 25,000 \text { ) }\end{array}$ & $\begin{array}{l}5,000- \\
10,000\end{array}$ & $500-5,000$ & $\begin{array}{c}1,000-50 \\
000 \text { (up to } \\
150,000 \text { ) }\end{array}$ & $\approx 2,000$ \\
\hline Polydispersity & $2.5-3.5$ & $2.5-3.5$ & $4.0-11.0$ & 1.5 & $4.2-7.0$ & - \\
\hline \multicolumn{7}{|c|}{$\begin{array}{l}\text { * Key data obtained from (Hol'kin (1989); Dong and Fricke (1995); Gonçalves and Benar (2001); } \\
\text { Lora and Glasser (2002); Gosselink et al. (2004); Shulga et al. (2005); El-Mansouri and Salvado } \\
\text { (2007); Carrott et al. (2008); Li and Gellerstedt (2008); Lora (2008); Park et al. (2008); El Hage et } \\
\text { al. (2009); Sun et al. (2009); Tan et al. (2009); Ungureanu et al. (2009); Mousavioun and Doherty } \\
\text { (2010); Holladay et al. (2007) }\end{array}$} \\
\hline \multicolumn{7}{|c|}{$\begin{array}{l}{ }^{* *} \mathrm{SL}=\text { Soda Lignin, } \mathrm{KL}=\mathrm{Kraft} \text { Lignin, } \mathrm{HL}=\text { Hydrolysis Lignin, OSL=Organosolv Lignin, } \\
\mathrm{LS}=\text { Lignosulphonates, ILL=Ionic Liquid Lignin }\end{array}$} \\
\hline
\end{tabular}

As seen in Table 1, kraft lignin (KL) and lignosulphonates (LS) have high ash and sulphur content. However, the content of sulphur in kraft lignin is quite low in compareson to LS, and sulphur in KL is mostly present in SH-bonds that are formed during cooking. This feature restricts utilization of these lignins in some demanding applications such as synthesis of polymers and low-molecular substances. Sulphur is difficult to 
remove, as it is chemically bonded to lignin. Sulphur is poisonous for catalysts and can cause odor problems. It should be mentioned that soda lignin from hardwoods is almost ash-free, while non-wood soda lignin contains a significant amount of ash and nitrogen. Hydrolysis lignin has many condensed structures, produced by dehydration reactions between the benzylic carbon atoms and the reactive sites of the aromatic ring. These structures have poor reactivity (Matsushita et al. 2009). Organosolv and ionic liquid lignins have the lowest molecular weights among the technical lignins and can be dissolved in certain solvents, which facilitates their further processing. However, in certain applications, high molecular weight is favorable. For instance the addition of ultra-high molecular weight lignosulphonates significantly improves the plasticizing properties of LS (Areskogh and Henriksson 2011). It should be mentioned that the data in Table 1 cover information on the properties of lignin from different sources i.e. nonwood, softwood, hardwood. Lignin from non-wood plants typically has lower molecular weight, higher polydispersity, and higher ash content than wood lignin.

According to Lora and Glasser (2002) and Li and Gellerstedt (2008), lignins to be used in polymer production should be free of sugars, have high Klason lignin content, and be sulphur-free.

\section{CHALLENGES IN THE USE OF TECHNICAL LIGNINS}

Technical lignins are mainly used as a fuel, despite the existence of a great number of potential applications of high added value. On the one hand, the commercial potential of these applications does not match existing production of lignin; e.g. the production of lignin is too high and not enough promising applications exist to fully realize lignin's potential. On the other hand, the quality of the lignin-based products in well-established fields, e.g. adhesives, sorbents and dispersants, is not always superior to the quality of existing products. Clearly there is a need for applications utilizing technical lignins and operating on a large scale. Opportunities for success would be enhanced by the introduction of very-high-quality lignin-based products exceeding the properties of petroleum-based products. Another option would be the development of new, lowtonnage, high-added value products. In addition to economic factors, the use of technical lignin is also hampered by technical problems. The majority of these problems are caused by the structural features of technical lignins and to some extent by the delignification methods. Identified problems have been divided into the four major classes.

\section{Recovery from the Products Stream}

Technical lignins are considered as by-products of integrated pulp mills and biorefinery sites. The lignin-rich streams from such sites contain many components that should be removed or recycled. Lignin-containing streams from major sources (kraft, LS, and soda lignins) contain around 20 to $40 \%$ dissolved lignin as dry solids, while the other part is composed of undissolved pulp and extractives. The pulp is separated in multistage pressurized filters; extractives, composed of fatty and rosin acids, are skimmed from the surface of the liquor. 
After these operations, the lignin-reach stream contains lignin, inorganic residuals from cooking, and some of the extractives. Black liquor, the spent liquid phase after kraft pulping, has a $\mathrm{pH}$ in the range of 9 to 10 . Spent sulfite liquor can have $\mathrm{pH}$ in the range of 2 to 12, depending on the type of the cooking method (Gullichsen and Fogenholm 2000).

Kraft lignin can easily be separated from black liquor. There are two main approaches for the separation process - filtration and precipitation. At the moment, precipitation of kraft lignin is the most usual method for the separation of lignin (Jönsson and Walberg 2009). Precipitation is usually done by two-step acidification. In the first step black liquor is acidified with carbon dioxide to $\mathrm{pH} 9$ to 10 ; as a result $75 \%$ of lignin is precipitated in the form of a sodium salt. In the second step, lignin is suspended in water and purified by addition of sufficient sulphuric acid to lower the $\mathrm{pH}$ below 3 (Lebo et al. 2001). Sulfuric acid treatment increases the sulfur content of lignin, and hence, usage of such lignins should be avoided in sulfur-sensitive applications (Loutfi et al. 1991). Finally, filtration is applied in order to separate lignin. It should be mentioned that the precipitation method of recovery is very sensitive to the concentration of black liquor. The optimal concentration for precipitation has been reported to be 27 to $30 \%$ based on dry solids (Loutfi et al. 1991). Axelsson et al. (2006) have calculated the cost associated with the extraction of lignin by $\mathrm{CO}_{2}$ precipitation as 25.5-38.5 $€$ per ton of lignin, noting that the cost is dependent on varying $\mathrm{CO}_{2}$ prices.

Ultrafiltration is considered as another option for separation of kraft lignin. Jönsson and Wallberg (2009) have conducted a comprehensive study of the recovery of kraft lignin by ultrafiltration. The major advantages of this method are: flexibility (it can be applied at any position in the mill) and the possibility to separate lignin without altering $\mathrm{pH}$ and temperature. It has been stated that ultrafiltration is economically feasible on an industrial scale. According to the Jönsson and Walberg (2009) the cost associated with the extraction of hardwood lignin from black liquor by ultrafiltration was calculated to be $60 €$ per ton of lignin at $90 \%$ volume reduction. The cost of the extraction is lower when the volume reduction is lower, for instance for $66 \%$ volume reduction cost drops to $17 €$ per ton of lignin. However, because lignins extracted by ultrafiltration contain substantial amount of hemicelluloses (up to $50 \mathrm{~g} / \mathrm{L}$ ) and ash (up to $0.47 \mathrm{~g} / \mathrm{g}$ solids), there would be a need in additional procedures for purification of lignin, which would increase the cost of the whole separation process.

In both separation methods, special efforts should be made to deodorize and decolorize the recovered technical lignins. Otherwise, their potential for utilization in some delicate applications could be strongly reduced. The dark color of lignins originates from their chemical structure. Color arises due to chromophores, which are the lightabsorbing groups and bonds in technical lignins. This problem can be solved by addition of bleaching agents such as ozone, hydrogen peroxide, and chlorine dioxide, noting that bleaching also can be done in case of mechanical pulps containing high amounts of lignin (Gullichsen and Fogenholm 1999). Technical lignins by themselves do not have an unpleasant odor; rather the objectionable smells originate from compounds formed during separation processes. This aspect is especially important in the case of sulphur-containing lignins because of their characteristic odor. The problem of odor can be solved by further purification or by addition of oxidizing chemicals such as hydrogen peroxide or chlorine dioxide. 
Soda lignin can be separated in the same way as kraft lignin. In this case there is no need to deodorize the liquor. Recovery of non-wood soda lignin by filtration and centrifugation could cause problems due to the high content of carboxylic groups, which make lignin highly hydrophilic (Doherty et al. 2011). However, separation of lignin from spent liquors significantly improves the environmental situation at small non-wood based mills lacking a chemical recovery system (Jönsson and Wallberg 2009). Abächerli and Doppenberg (1998) have patented a method for isolation of soda lignin by precipitation.

Lignosulphonates are traditionally separated from spent liquor by ultrafiltration. Lignosulphonates are easier to separate than other lignins because of the higher molecular weight of the lignin fragments (Jönsson and Wallberg 2009). It is beneficial to remove carbohydrates from the liquor prior to ultrafiltration. Membrane separation methods allow for efficient separation of lignosulphonates and sugars. However, only the high molecular weight fraction of LS can be effectively separated from sugars and recovered; in this case retention of sugars can be as low as 3\% (Restolho et al. 2009).

The other types of technical lignin, such as organosolv and ionic liquid lignins, can be recycled by addition of a non-solvent, e.g., water (Sun et al. 1998; van Spronsen et al. 2011). Macfarlane et al. (2008) have used dissolved air flotation for the recovery of organosolv lignin from Salix Shwerinii and reported the efficient separation of lignin at temperatures below $35^{\circ} \mathrm{C}$.

Hydrolysis lignin is composed of solid lignin residuals. It should be mentioned that hydrolysis lignin could contain significant amounts of unhydrolyzed cellulose, up to $15 \%$; hydrolysis lignin having a high residual cellulose content can be regarded as "cellulignin" (Hol'kin 1989). The percentage of residual cellulose is usually higher for enzymatic hydrolysis lignin. Since hydrolysis lignin appears in a solid form, there is no need for the use of sophisticated recovery methods, it can be filtrated through a fine mesh. Nevertheless, mechanically recovered lignins contain various impurities. Cheng et al. (2007) have used $\mathrm{NaOH}$ extraction in order to obtain lignin for use in production of polyurethane. Another aspect of hydrolysis lignin recovery is the high water retention ability of these lignins (Hol'kin 1989), limiting utilization of hydrolysis lignin as a fuel.

Methods for the recovery of technical lignins are summarized in Table 2. As can be seen from the table, most of the methods for lignin recovery have been demonstrated only in the laboratory or/and at pilot scale, and only kraft lignin and lignosulphonates have been recovered at an industrial scale. Unfortunately, none of above mentioned separation methods is able to provide a pure lignin that can be readily subjected to chemical transformation. Often, recovered lignins contain significant amounts of organic and inorganic impurities. Precipitation and ultrafiltration of lignin are established processes, while other methods are just emerging. Two main goals in separation of technical lignins are cost-effectiveness and quality of the obtained lignins.

\section{Purification of Lignins}

Technical lignins can contain various impurities such as sugars, silicates, sulphur, ash, proteins, and other compounds originating either from the raw material or the delignification process (El Mansouri and Salvadó 2006). In order to be used in chemical or biochemical conversion processes, technical lignins have to be purified first. Impurities such as carbohydrates, extractives and inorganics should be removed. 
Table 2. Methods for Separation and Recovery of Technical Lignins from Product Streams

\begin{tabular}{|c|c|c|c|}
\hline $\begin{array}{l}\text { Type of } \\
\text { lignin }\end{array}$ & Separation Method & Status & References \\
\hline \multirow[t]{2}{*}{ Kraft } & Precipitation ( $\mathrm{pH}$ change) & Industrial & $\begin{array}{l}\text { Loutfi et al. (1991), Lebo et al. } \\
\text { (2001), Axelsson et al. (2006), } \\
\text { Jönsson and Walberg (2009) }\end{array}$ \\
\hline & Ultrafiltration & Industrial & $\begin{array}{l}\text { Mänttäri and Nyström (2009), } \\
\text { Jönsson and Wallberg (2009) }\end{array}$ \\
\hline \multirow[t]{2}{*}{ Soda } & Precipitation ( $\mathrm{pH}$ change) & Laboratory/Pilot & $\begin{array}{c}\text { Abächerli and Doppenberg } \\
\text { (1998), Ghatak (2008), } \\
\text { Mousavioun and Doherty (2010) }\end{array}$ \\
\hline & Ultrafiltration & Laboratory & $\begin{array}{l}\text { Toledano et al. (2010a and } \\
2010 \mathrm{~b})\end{array}$ \\
\hline LS & Ultrafiltration & Industrial & $\begin{array}{l}\text { Mänttäri and Nyström (2009), } \\
\text { Restolho et al. (2009) }\end{array}$ \\
\hline \multirow{2}{*}{$\mathrm{HL}$} & Filtration & Industrial/Pilot & Hol'kin (1989), Dalimova (2006) \\
\hline & Extraction $(\mathrm{NaOH})$ & Laboratory & Cheng et al. (2007) \\
\hline \multirow[b]{2}{*}{ OSL } & Dissolved Air Flotation & Laboratory & Macfarlane et al. (2008) \\
\hline & $\begin{array}{c}\text { Precipitation (addition of } \\
\text { non-solvent) }\end{array}$ & Laboratory/Pilot & $\begin{array}{l}\text { Cook et al. 1991, Sun et al. } \\
\text { (1998) }\end{array}$ \\
\hline ILL & $\begin{array}{c}\text { Precipitation (addition of } \\
\text { non-solvent) }\end{array}$ & Laboratory & van Spronsen et al. (2011) \\
\hline
\end{tabular}

It has been suggested that the highest extent of purification is needed when lignins are to be utilized in chemical synthesis of low-molecular weight substances or polymers (El Mansouri and Salvadó 2006 and 2007). If not removed, impurities can cause the formation of undesirable by-products, result in lower yields, and lead to deterioration in the properties of final products. Moreover, some impurities, such as sulfur, can poison catalysts used in chemical conversion processes.

Residual sugars contained in technical lignins can significantly reduce their value as raw materials. Despite this problem, efficient methods for the separation of sugars from lignin exist. The different solubility of the precipitated sugars allows them to be removed from lignin by acid/base extraction. Extraction is widely applied in the separation of alkali lignins; however, when the carbohydrates are bonded to lignin chemically, these sugars can cause considerable difficulties in the separation process. Argyropolous et al. (2002) have proposed a two-stage method (enzymatic hydrolysis followed by acid hydrolysis) for the isolation of kraft lignin, and it was mentioned that this method provides around 100\% of sugars removal from lignin. The spent sulphite liquor contains a substantial part of hemicelluloses, and these sugars can be chemically bonded with lignosulphonates. Both lignosulphonates and sugars are soluble in water, and as a consequence it is quite difficult to separate them from each other (Lora 2008). At sulphite pulp mills, fermentation of sugars is used to separate sugars from sulphonated lignin. Unfortunately, the spent sulfite liquors contain inhibitors to fermentation, such as organic acids and aldehydes, and specialized methods are needed to make sulphite spent liquors fermentable. Nevertheless, methods such as ultrafiltration and precipitation can also be used for the separation of the lignosulphonates (Lora 2008). 
Ash and other water-soluble inorganic impurities can be removed simply by washing with water. Nitrogen in lignins is present in organic form (proteins, amino acids) and originates from the raw material (Niemelä 1990; Veverka and Nichols 1992 ). One possible opportunity to remove nitrogen-containing substances from lignin is by treatment with proteolytic enzymes such as proteases. Sulphur is difficult to separate, especially from kraft lignin and lignosulphonates, where it is chemically bonded to the lignin. In kraft lignin about $70 \%$ of the sulphur is organically bound sulphur, while $30 \%$ can be removed by washing (Svensson 2008). Raney nickel reduction is one method to remove sulphur from lignin. However, this method is quite costly and difficult to implement in industry (Beigi et al. 1999; Svensson 2008). Thiobacillus bacteria could possibly be used for microbial removal of sulphur from lignin; the bacteria have shown good efficiency in removal of sulphur from coal (Narayan and Ho 1988). Sulphur is poisonous for most industrial catalysts (Gonçalves and Benar 2001), and for applications where the absence of sulphur is crucial, sulphur-free lignins should be used, as none of the above-mentioned methods can ensure the total removal of sulphur.

There are several methods for the removal of silica from spent liquors from nonwood pulping. Carbonation is the most widely applied approach, and it is possible to remove up to $70 \%$ of the silica by this method (Mandavgane et al. 2007). Desilication can also be performed by calcium oxide and sulphuric acid methods. These methods have been reviewed in Nepenin and Nepenin (1994). Silica is an inert material, and for this reason removal of silica is not obligatory for most applications. Nitrogen from lignin can be removed by hot water treatment or by treatment with protease (Dorado et al. 2001).

Many methods exist for the purification of lignin impurities. Unfortunately, the use of these methods is not always justified economically. Moreover, it should be noted, that separation methods cannot ensure complete removal of compounds chemically bonded to lignin.

\section{Non-Uniform Structure}

The structure of technical lignins differs considerably, with variations in polymer composition, size, and degree of crosslinking, and the presence of functional groups. The most essential differences are found in the monomer composition and linkage type in the lignin fragments. Furthermore, lignin composition varies both according to its origin and within the tissues of individual plants. While $95 \%$ of softwood lignin is composed of guaiacyl units, other plants (hardwoods, straw) show a more heterogeneous composition, creating a mixture of three types of phenylpropanoid units. Lignin has several major types of functional groups: hydroxyl, methoxyl, carbonyl, and carboxyl. The number of groups and their relative amount depends on the origin of the lignin and extraction procedure applied. Technical lignins are a mixture of lignin fragments of different molecular weight and polydispersity. Polydispersity increases, from lowest to highest, in the following order: organosolv lignin, soda lignin, kraft lignin, and lignosulphonates.

Controlled degradation is one method for reaching a specific degree of structural uniformity of lignin fragments. Degradation can be performed by either a chemical or enzymatic pathway (Hofrichter 2002; Matsushita et al. 2008). The aim of controlled degradation of lignin is to obtain fragments of molecular weight $\left(M_{w}\right)$ within specified intervals; $M_{w}$ intervals should be chosen according to the final use of the lignin. Several 
approaches for controlled degradation exist. The fragments of lignin with the defined $M_{w}$ interval can be isolated by adding a solvent or mixture of solvents with a pre-defined concentration targeted on the specific $M_{w}$ of the fragments. Yuan et al. (2010) have treated alkali lignin with an ethanol- $\mathrm{NaOH}$ mixture at elevated temperature. Original lignin with $M_{w} 10,000$ to $60,000 \mathrm{~g} /$ mol was degraded into soluble fragments with a narrower molecular weight distribution of 450 to $1000 \mathrm{~g} / \mathrm{mol}$. The addition of naphtol-2 during isolation of lignin can prevent condensation reactions, improve lignin's reactivity, and decrease the molecular weight of the lignin fragments. The naphtol-2 acts as a carbonium ion scavenger (Li and Gellerstedt 2008). Lignin can also be degraded under pyrolytic conditions; unfortunately, pyrolysis entails free-radical reactions, and therefore it cannot produce lignin fragments with a pre-defined structure (Faravelli et al. 2010). A further method for the controlled degradation of lignin is chemical oxidation together with microwave irradiation (Ouyang et al. 2010). Such treatment allows narrow $M_{w}$ distributions to be produced.

As mentioned earlier, the structure of lignin can be modified via enzymatic reactions. However, at present, these methods require significant research efforts. SenaMartins et al. (2008) have reviewed a current state-of-art application of enzymaticallymodified lignins. Some applications require fragments with higher $M_{w}$ than the $M_{w}$ of the initial technical lignin. One way to increase the molecular weight of lignin polymers is oxidative polymerization by laccases (Areskogh et al. 2010b). It is not clear how to homogenize the lignin's structure, as none of the above-mentioned methods can produce identical chain fragments of lignin. There is an acute need to develop effective methods for homogenization of lignin.

\section{Unique Reactivity}

The chemical reactivity of technical lignins is a cornerstone of many applications. Due to their heterogeneous structure, lignins often show unexpected behavior. Uniformity of structure is especially important for technical lignins destined to be used in formulations of synthetic resins. As technical lignins contain different functional groups, they can react in many ways, only one of which may be desirable. The reactivity of lignin and its structure are closely related. The reactivity of the lignin is limited because of the small number of ortho and para reactive sites and their poor accessibility (Alonso et al. 2004). Methods for enhancing reactivity use the following approaches: decreasing the molecular weight by oxidative and other methods, modifiying the structure in order to increase the amount of particular functional groups, and isolating lignin fragments with a specified $M_{w}$ and structure.

At present there are two main ways to improve lignin's reactivity (Yuan et al. 2010). The first method is depolymerization of lignin to oligomers and monomers, and the second is the introduction of reactive sites in the lignin molecules by phenolation (Matsushita and Yasuda 2003). Depolymerization of lignin improves accessibility of reactive sites while reactivity in ortho and para positions remains the same (Yuan et al. 2009). Enzymes can be used to improve lignin reactivity, for instance, by utilization of laccases to promote oxidation reactions of lignin. These reactions lead to the formation of new reactive sites (Felby et al. 1998). 
Yuan et al. (2009) have combined depolymerization with a phenolation reaction. In this case phenol was used as a capping agent. The treatment produced depolymerized lignin with good reactivity. Phenolic-OH groups ensure good reactivity of lignin, while aliphatic-OH groups can have a negative influence on reactivity, since they favor carbohydrate bonding ( $\mathrm{Li}$ and Gellerstedt 2008). The amount of phenolic hydroxyl groups can be increased by chemical reduction using sodium dithionite (Dence and Reeve 1996).

The study of Wang et al. (2010) proposes utilization of the genetic regulation of the gene family encoding coniferyl-aldehyde-5-hydrolase (CAI5dh) in order to control lignin's structure and its reactivity. This approach is very promising, as it allows control of the structure of lignin genetically. However, it is not likely that this method will be realized in the nearest future. Genetic modification of lignins has been discussed elsewhere (Li et al. 2008; Weng et al. 2008).

\section{SUMMARY}

Biorefining of lignocellulosic material is developing rapidly. The key to effective development of biorefining is identification of effective methods for the conversion of lignocellulosic materials. Technologies exist for isolation and conversion of sugars and vegetable oils from plant biomass. However, such technologies have not yet been proposed for the isolation and conversion of lignin. The residuals from integrated pulp mills and biorefinery sites - lignin-rich streams - are generally burnt for process steam and energy. These lignin-rich streams could be used for the production of technical lignins, including kraft, soda, organosolv, hydrolysis, steam explosion lignins, and lingosulphonates. Technical lignins are very diverse in terms of their molecular weight, structure, chemical reactivity, and chemical composition, which is a consequence of the differing origin of the lignin and the various methods of lignin isolation.

In this paper, four major classes of problems have been identified: recovery of lignins from the product stream, purification of lignins, the heterogeneous structure of lignins, and the unique reactivity of lignins. Methods exist to overcome the first two problems. However, economic considerations limit their broad use. From a technological point of view, major concerns are associated with the last two problems - heterogeneous structure and unique reactivity. Existing methods can solve these problems only partially. Nevertheless promising approaches are emerging, for example, genetic modification of lignin, which would permit design of lignin molecules for specific applications.

\section{ACKNOWLEDGEMENTS}

The authors would like to thank Mr. Peter G. Jones for the language check of manuscript. 


\section{REFERENCES CITED}

Abächerli, A. (1998). "Method for precipitation of aromatic polymers from alkaline wastewater from pulping," Patent WO 9842912.

Abächerli, A., and Dopenberg, F. (1998). "Method for preparing alkaline solutions containing aromatic polymers," Int. patent. WO9842912.

Alonso, M. V., Oliet, M., Pérez, J. M., Rodríguez, and Echeverría, J. (2004).

"Determination of curing kinetic parameters of lignin-phenol-formaldehyde resol by several dynamic differential scanning calorimetry methods," Thermochim. Acta 419 (1-2), 161-167.

Alonso, M. V., Oliet, M., Rodríguez, F., Astarloa, G., and Echeverría, J. M. (2004). "Use of a methylolated softwood ammonium lignosulfonate as partial substitute of phenolin resol resins manufacture," J. Appl. Polym. Sci. 94 (2), 643-650.

Ansari, A., and Pawlik, M. (2007). "Floatability of chalcopyrite and molybdenite in the presence of lignosulfonates. Part I. Adsorption studies," Miner. Eng. 20 (6), 600-608.

Areskogh, D., Li, J., Gellerstedt, G., and Henriksson, G. (2010). "Investigation of the molecular weight increase of commercial lignosulfonates by laccase catalysis," Biomacromolecules 11(4), 904-910.

Areskogh, D., and Henriksson, G. (2011). "Immobilisation of laccase for polymerization of commercial lignosulphonates," Process Biochemistry, Article in Press.

Areskogh, D., Li, J., Gellerstedt, G., and Henriksson, G. (2010). "Structural modification of commercial lignosulphonate through laccase catalysis and ozonolysis," Industrial Crops and Products 32(3), 458-466.

Argyropolous, D. S. (2008). "Use of lignocellulosics solvated in ionic liquids for production of biofuels," US Patent 2008/0190013 A1

Argyropoulus, D. S., Sun, Y., and Paluš, E. (2002). "Isolation of kraft residual kraft lignin in high yield and purity," Journal of Pulp and Paper Science 28(2), 50-54.

Axelsson, E., Olsson, M. R., and Berntsson, T. (2006). "Increased capacity in kraft pulp mills: Lignin separation and reduced steam demand compared with recovery boiler upgrade," Nordic Pulp Paper Res. J. 21(4), 485-492.

Baklanova, O. N., Plaksin, G. V, Drozdov, V. A., Duplyakin, V. K., Chesnokov, N. V., and Kuznetsov, B. N. (2003). "Preparation of microporous sorbents from cedar nutshells and hydrolytic lignin," Carbon 41(9), 1793-1800.

Baurhoo, B., Ruiz-Feria, C. A., and Zhao, X. (2008). "Purified lignin: Nutritional and health impact on farm animals - A review," Animal Feed Science and Technology 144(3), 175-184.

Beigi, M. A. A. Teymouri, M., Eslami, M., and Farazmand, M. (1999). "Determination of tracesulphur in organic compounds by activated Raney nickel desulphurization method with nondispersive gas detection system," Analyst 124(5), 767-770.

Belgacem, M. N., Blayo, A., and Gandini, A. (2003). "Organosolv lignin as a filler in inks, varnishes, and paints," Industrial Crops and Products 18(2), 145-153.

Betancur, M., Bonelli, P. R., Velásquez, J. A., and Cukierman, A. L. (2009). "Potentiality of lignin from the kraft pulping process for removal of trace nickel from wastewater: Effect of demineralization," Bioresource Technology 100(3), 1130-1137. 
Binder, J. B., Gray, M. J., White, J. F., Zhang, C. Z., and Holladay J. E. (2009). "Reactions of lignin model compounds in ionic liquids," Biomass and Bioenergy 33(9), 1122-1130.

Buranov, A. U. and Mazza, G. (2008). "Lignin in straw of herbaceous crops,"' Industrial Crops and Products 28(3), 237-259.

Carrott, P. J. M., Suhas, M. M. L., Carrott, R., Guerrero, C. I., and Delgado, L. A. (2008). "Reactivity and porosity development during pyrolysis and physical activation in $\mathrm{CO}_{2}$ or steam of kraft and hydrolytic lignins," J. Anal. Appl. Pyrolysis 82 (2), 264-271.

Carrott, S., and Carrott, R. (2007). "Lignin - from natural adsorbent to activated carbon: A review," Bioresource Technology 98(12), 2301-231.

Cazacu, G., Pascu, C., Profire, L., Kowarskik, A. L., Mihaies, M., and Vasile, C. (2004). "Lignin role in a complex polyolefin blend," Industrial Crops and Products 20(2), 261-273.

Chakar, F. S., and Ragauskas, A. J. (2004). "Review of current and future softwood kraft lignin process chemistry," Industrial Crops and Products 20(2), 131-141.

Chandra, R. P., Bura, R., Mabee, W. E., Berlin, A., Pan, X., and Saddler, J. N. (2007). "Substrate pretreatment: The key to effective enzymatic hydrolysis of lignocellulosics?" Adv. Biochem. Eng. Biotechnol. 108, 67-93.

Cheng, X. S., Liu, X. L., and Jin, Y. Q. (2007). "Study on EH lignin as a novel additive for polyurethane industry," Polyurethane Industry 22(6), 18-21.

Cherubini, F. (2010). "The biorefinery concept: Using biomass instead of oil for producing energy and chemicals," Energy Conversion and Management 51(7), 1412 1421.

Cook, P. M. and Hess, S. L. (1991). "Organosolv lignin-modified phenolic resins and method for their preparation," US Patent 5,010,156.

Jin, C. D., Li, S., Liu, L., Ye, J. W., and Du, C. D. (2011). "Research of process on making bamboo particle board by laccase-treated calcium lignosulfonate," Advanced Materials Research 179-180, 1031.

Dalimova, G. N. (2006). "Modification of hydrolyzed lignin in acidic and basic media," Chemistry of Natural Compounds 42(1), 88-91.

Demirbas, A. (2009). Biorefineries: For Biomass Upgrading Facilities, Springer, Berlin, ISBN: 1848827202

Dence, C. W., and Reeve, D. W. (1996). Pulp Bleaching: Principles and Practice, TAPPI Press, Atlanta Georgia.

Dizhbite, T., Zakis, G., Kizima, A., Lazareva, E., Rossinskaya, G., Jurkjane, V., Telysheva, G., and Viesturs, U. (1999). "Lignin: A useful bioresource for the production of sorption-active materials," Bioresour. Technol. 67(3), 221-228.

Doherty, W., Mousaviouna, P., and Fellows C. (2011). "Value-adding to cellulosic ethanol: Lignin polymers," Industrial Crops and Products 33(2), 259-276.

Donaldson, L. A. (2001). "Lignification and lignin topochemistry - An ultrastructural view," Phytochemistry 57(6), 859-873.

Dong, D., and Fricke, A. L. (1995). "Intrinsic viscosity and the molecular weight of kraft lignin," Polymer 36(10), 2075-2078.

Dorado, J., Field, J. A., Almendros, G., and Sierra-Alvarez R. (2001). "Nitrogen-removal with protease as a method to improve the selective delignification of hemp stemwood 
by the white-rot fungus Bjerkandera sp. strain BOS55," Appl. Microbiol. Biotechnol. 57(1-2), 205-211.

El Hage, R., Brosse, N., Chrusciel, L., Sanchez, C., Sannigrahi, P., and Ragauskas, A. (2009). "Characterization of milled wood lignin and ethanol organosolv lignin from Miscanthus," Polymer Degradation and Stability 94(10), 1632-1638.

El Mansouri, N.-E., and Salvadó, J. (2006). "Structural characterization of technical lignins for the production of adhesives: Application to lignosulphonate, kraft, sodaanthraquinone, organosolv and ethanol process lignins," Industrial Crops and Products 24(1), 8-16.

El-Mansouri, N.-E., and Salvadó, J. (2007). “Analytical methods for determining functional groups in various technical lignins," Industrial Crops and Products 26(2), 116-124.

Fagerholm-Byman, H., Mikkola, P., Rosenholm, J. B., Lindén, E., and Carlsson, R. (1999). "The infuence of lignosulphonate on the properties of single and mixed $\mathrm{Si}_{3} \mathrm{~N}_{4}$ and $\mathrm{ZrO}_{2}$ suspensions," Journal of the European Ceramic Society 19(1), 41-48.

Fan, J., and Zhan, H. (2008). "Optimization of synthesis of spherical lignosulphonate resin and its structure characterization," Chinese Journal of Chemical Engineering 16(3), 407-410.

Faravelli, T., Frassoldati, A., Migliavacca, G., and Ranzi, E. (2010). "Detailed kinetic modeling of the thermal degradation of lignins," Biomass and Bioenergy 34(3), 290301.

Fasching, M., Schröder, P., Wollboldt, R. P., Weber, H. K., and Sixta, H. (2007). "A new and facile method for isolation of lignin from wood based on complete wood dissolution," Holzforschung 62(1), 15-23.

Felby, C., Olesen, P. O., and Hansen, T. T. (1998). "Laccase catalysed bonding of wood fiber," In: Enzymes in Fiber Processing, ACS Symposium Series 687, Washington, DC, 88-98.

Fierro, V., Torne, V., Montane, D., and Salvadó, J. (2003). “Activated carbons prepared from kraft lignin by phosphoric acid impregnation," Carbon' 03. ISBN-84-607-83057.

FitzPatrick, M., Champagne, P., Cunningham, M. F., and Whitney, R. A. (2010). “A biorefinery processing perspective: Treatment of lignocellulosic materials for the production of value-added products," Bioresource Technology 101(23), 8915-8922.

García, A., Toledano, A., Serrano, L., Egüés, M., Gonzaléz, M., Marín, F., and Labidi, J. (2009). "Characterization of lignin obtained by selective precipitation," Separation and Purification Technology 68(2), 193-198.

Gellerstedt, G., and Henriksson, G. (2008). "Lignins: Major sources, structure and properties," In: Belgacem, M., and Gandini, A. (eds.), Monomers, Polymers and Composites from Renewable Resources, Elsevier, ISBN: 978-0-08-045316-3.

Ghatak, H. R. (2008). "Spectroscopic comparison of lignin separated by electrolysis and acid precipitation of wheat straw soda black liquor," Industrial Crops and Products 28(2), 206-212.

Gonçalves, A. R., and Benar, P. (2001). "Hydroxymethylation and oxidation of organosolv lignins and utilization of the products," Bioresource Technology 79(2), 103-111. 
Gonzalez-Garcia, S., Moreira, T. M., Artal, G., Maldonado, L., and Feijooa, G. (2010). "Environmental impact assessment of non-wood based pulp production by soda athraquinone pulping process," Journal of Cleaner Production 18(2), 137-145.

Gosselink, R. J. A., Abächerli, A., Semke, H., Malherbe, R., Käuper, P., Nadif, A., and van Dam, J. E. G. (2004). "Analytical protocols for characterization of sulphur-free lignin," Industrial Crops and Products 19(3), 271-281.

Gosselink, R. J. A., de Jong, E., Guran, B., and Abächerli, A. (2004). “Co-ordination network for lignin - Standardisation, production and applications adapted to market requirements (EUROLIGNIN)," Industrial Crops and Products 20(2), 121-129.

Gosselink, R. J. A., de Jong, E., Abächerli, A., and Guran, B. (2005). "Activities and results of the thematic network EUROLIGNIN," In: Proceedings of the International Lignin Institute 7th Forum, Barcelona, 25-30.

Grierson, L. H., Knight, J. C., and Maharaj, R. (2005). "The role of calcium ions and lignosulphonate plasticiser in thehydration of cement," Cement and Concrete Research 35(4), 631-636.

Gullichsen, J., and Fogenholm, C.-J. (2000). "Chemical pulping,” In: Gullichsen, J., and Paulapuro, H. (eds.), Papermaking Science and Technology, Book 6A. Chemical Pulping, Jyväskylä, Fapet Oy.

Hamelinck, C. N., van Hooijdonk, G., and Faaij, A. P. C. (2005). "Ethanol from lignocellulosic biomass: Techno-economic performance in short- , middle- and longterm," Biomass Bioenerg. 28(4), 384-410.

Harmita, H., Karthikeyan, K. G., and Pan, X.-J. (2010). "Copper and cadmium sorption onto kraft and organosolv lignins," Bioresource Technology 100(24), 6183-6191.

Hofrichter, M. (2002). "Review: Lignin conversion by manganese peroxidase (MnP)," Enzyme Microb. Technol. 30(4), 454-466.

Hol'kin, Y. (1989). Tehnologiya Gidroliznih Proizvodstv (The technology of wood' hydrolysis). Lesnaya Promishlennost'. ISBN-5-7120-0158-6. 496p. Book in Russian.

Holladay, J. E., Bozell, J. J., White, J. F., and Johnson, D. (2007). “Top value-added chemicals from biomass. Volume II- Results of screening for potential candidates from biorefinery lignin," A report. Available via: http://www1.eere.energy.gov/biomass/pdfs/pnnl-16983.pdf

Iranmahboob, J., Nadim, F., and Monemi, S. (2002). "Optimizing acid-hydrolysis: A critical step for production of ethanol from mixed wood chips," Biomass Bioenergy 22(5), 401-404.

Jin, Y., Cheng, X., and Zhen, Z. (2010). "Preparation and characterization of phenolformaldehyde adhesives modified with enzymatic hydrolysis lignin," Bioresource Technology 101(6), 2046-2048.

Jöhnson, D. K., Bozell, J., Holladay, J. E., and White, J. F. (2005). "Use of lignin in the biorefinery," In: Proceedings of the International Lignin Institute 7th Forum, Barcelona, 31-34.

Jönsson, A.-S., Nordin, A.-K., and Wallberg, O. (2008). "Concentration and purification of lignin in hardwood kraftpulping liquor by ultrafiltration and nanofiltration," Chemical Engineering Research and Design 86(11), 1271-1280.

Jönsson, A.-S., and Wallberg, O. (2009). "Cost estimates of kraft lignin recovery by ultrafiltration,” Desalination 237(1-3), 254-267. 
Kadla, J. F., Kubo, S., Venditti, R. A., Gilbert, R. D., Compere, A. L., and Griffith, W. (2002). "Lignin-based carbon fibers for composite fiber applications," Carbon 40(15), 2913-2920.

Kubo, S., Uraki, Y., and Sano, Y. (1998). "Preparation of carbon fibers from softwood lignin by atmospheric acetic acid pulping," Carbon 36(7-8), 1119-1124.

Lebo, S. E., Gargulak, J. D., and Timothy, J. M. (2001). "Lignin,” In: Kirk-Othmer Encyclopedia of Chemical Technology (4th ed.), John Wiley and Sons, New York.

Li, J., and Gellerstedt, G. (2008). "Improved lignin properties and reactivity by modifications in the autohydrolysis process of aspen wood," Industrial Crops and Products 27(2), 175-181.

Li, X., Weng, J.-K., and Chapple, C. (2008). "Improvement of biomass through lignin modification," The Plant Journal 64(4), 569-581.

Lora, J. (2008). "Industrial commercial lignins: Sources, properties and applications," In: Belgacem, M., and Gandini, A. (eds.), Monomers, Polymers and Composites from Renewable Resources, Elsevier, ISBN: 978-0-08-045316-3.

Lora, J. H., Creamer, A. W., Wu, C. F., and Goyal, G. C. (1993). "Industrial scale production of organosolv lignins; Characteristics and applications," In: Kennedy, J. F. (ed.), Cellulosics: Chemical, Biochemical and Material Aspects, Ellis Horwood Ltd, 251-256.

Lora, J. H., and Glasser, W. G. (2002). "Recent industrial applications of lignin: A sustainable alternative to nonrenewable materials," Journal of Polymers and the Environment 10(1-2), 39-48.

Loutfi, H., Blackwell, B., and Uloth, V. (1991). "Lignin recovery from kraft black liquor: Preliminary process design,” Tappi J. 74(1), 203-210.

MacFarlane, A. L., Prestidge, R., Farid, M. M., and Chen, J. J. J. (2009). "Dissolved air flotation: A novel approach to recovery of organosolv lignin," Chemical Engineering Journal 148(1), 15-19.

Mai, C., Milstein, O., and Hüttermann, A. (2000). "Chemoenzymatical grafting of acrylamide onto lignin," Journal of Biotechnology 79(2), 173-183.

Mandavgane, S., Paradkar, G. D., Varu, J., Pamar, R., and Subramanian, D. (2007). "Desilication of agro based black liquor and green liquor using jet loop reactor," Indian Journal of Chemical Technology 14(6), 606-610.

Matsushita, Y., Inomata, T., Hasegawa, T., and Fukushima, K. (2009). "Solubilization and functionalization of sulphuric acid lignin generated during bioethanol production from woody biomass," Bioresource Technology 100(2), 1024-1026.

Matsushita, Y., Imai, M., Iwatsuki, A., and Fukushima, K. (2008). "The relationship between surface tension and the industrial performance of water-soluble polymers prepared from acid hydrolysis lignin, a saccharification by-product from woody materials," Bioresour. Technol. 99(8), 3024-3028.

Meister, J. J. (2002). "Modification of lignin," Journal of Macromolecular SciencePolymer Reviews 42(2), 235-289.

Mohan, D., Pittman, C. U., and Steele, P. H. (2006). "Single, binary and multicomponent adsorption of copper and cadmium from aqueous solutions on kraft lignin - a biosorbent," Journal of Colloid and Interface Science 297(2), 489-504. 
Mousavioun, P., and Doherty, W. O. S. (2010). "Chemical and thermal properties of fractionated bagasse soda lignin," Industrial Crops and Products 31(1), 52-58.

Muhammad, N., Man, Z., and Khalil, M. A. B. (2011). "Ionic liquid - a future solvent for the enhanced uses of wood biomass," Eur. J. Wood. Prod., Article in press

Mäki-Arvela, P., Anugwoma, I., Virtanen, P., Sjöholm, R., and Mikkola, J. P. (2010). "Dissolution of lignocellulosic materials and its constituents using ionic liquids. A review," Industrial Crops and Products 32(3), 175-201.

Mänttäri, M., and Nyström, M. (2009). "Utilization of membrane processes in treating various effluents generated in pulp and paper industry," 981-1007, In: Pabby, A. K., Rizvi, S. S. H., and Sastre, A. M. (2009). Handbook of Membrane Separations: Chemical, pharmaceutical, Food and Biotechnological Applications, CRC Press New York.

Mäntyniemi, J. (2010). "Novel solutions for pulp mill energy intensification," Results Pulp and Paper 3, 46-49.

Mörck, R., Yoshida, H., Kringstad, K., and Hatakeyama, H. (1986). "Fractionation of kraft lignin by successive extraction with organic solvents. Functional groups, ${ }^{13} \mathrm{C}$ NMR-spectra and molecular weight distributions," Holzforschung 40, 51-60.

Nadif, A., Hunkeler, D., and Käuper, P. (2002). "Sulfur-free lignins from alkaline pulping tested in mortar for use as mortar additives," Bioresource Technology 84(1), 49-55.

Nakagame, S., Chandra, R. P., Kadla, J. F., and Saddler, J. N. (2011). "The isolation, characterization and effect of lignin isolated from steam pretreated Douglas-fir on the enzymatic hydrolysis of cellulose," Bioresource Technology 102(2), 4507-4517.

Narayan, R., and Ho, N. (1988). "Objectives of coal bioprocessing and approaches," ACS Division of Fuel Chemistry meeting Fall 1988 (LOS ANGELES) 33(4). available via: http://www.anl.gov/PCS/acsfuel/preprint\%20archive/Files/33 4 LOS\%20ANGELES 09-88 0487.pdf

Nepenin, N. N., and Nepenin, Y. N. (1994). Pulping Technology: Cleaning, Drying and Bleaching of Pulp. Other Pulping Methods, Moscow "Ekologia”. ISBN 5-7120-0464$\mathrm{x}$.

Niemelä, K. (1990). "Low-molecular-weight organic compounds in birch kraft black liquor," Ph.D. Thesis, Helsinki University of Technology.

Olivier-Bourbigou, H., Magna, L., and Morvan, D. (2011). "Ionic liquids and catalysis: Recent progress from knowledge to applications," Industrial Crops and Products 33(1-2), 259-276.

Ouyang, X., Lin, Z., Deng, Y., Yang, D., and Qiu, X. (2010). “Oxidative degradation of soda lignin assisted by microwave irradiation," Chinese Journal of Chemical Engineering 18(4), 695-702.

Palmqvist, L., Lyckfeldta, O., Carlström, E., Davous, P., Kauppi, A., and Holmberg, K. (2006). "Dispersion mechanisms in aqueous alumina suspensions at high solids loadings," Colloids and Surfaces A: Physicochemical and Engineering Aspects 274(1-3), 100-109.

Pan, X., Kadla, J. F., Ehara, K., Gilkes, N., and Saddler, J. N. (2006). “Organosolv ethanol lignin from hybrid poplar as a radical scavenger: Relationship between lignin 
structure, extraction conditions, and antioxidant activity," J. Agric. Food Chem. 54(16), 5806-5813.

Park, Y., Doherty, W. O. S., and Halleya, P. J. (2008). "Developing lignin-based resin coatings and composites," Industrial Crops and Products 27(2), 163-167.

Ramírez, R., González, V., Crespo, M., Meier, D., Faix, O., and Zúñiga, V. (1997). "Ammoxidized kraft lignin as a slow-release fertilizer tested on Sorghum vulgare," Bioresource Technology 61(1), 43-46.

Rastogi, S., and Dwivedi, U. N. (2008). "Manipulation of lignin in plants with special reference to O-methyltransferase," Plant Science 174(3), 264-277.

Restolho, J. A., Prates, A., Norberta de Pinho, M., and Dina Alfonso, M. (2009). "Sugars and lignosulphonates recovery from eucalyptus spent sulphite liquor by membrane process," Biomass and Bionergy 33(11), 1558-1566.

Rodriguez, A., Sancheza, R., Requejoa, A., and Ferrera, A. (2010). "Feasibility of rice straw as a raw material for the production of soda cellulose pulp," Journal of Cleaner Production 18(10-11), 1084-1091.

Saake, B., and Lehnen, R. (2007). “Lignin,” In: Ullmanns’s Encyclopedia of Industrial Chemistry.

Sazanov, Y. N, Kulokova, E. M, Fedorova, G. N., Popova, E. N., Litvinova, L. S., Kever, E. E., Mokeev, M. V., Sumerskii, I. V, Novoselova, A. V., and Gribanov, A. V. (2009). "Potential activity of hydrolytic lignin in copolymerization reactions," Russian Journal of Applied Chemistry 82(9), 1592-1599.

Sena-Martins, G., Almeida-Vara, E., and Duarte, J. C. (2008). "Eco-friendly new products from enzymatically modified industrial lignins," Industrial Crops and Products 27(2), 189-195.

Shulga, G., Rekner, F., and Varslavan, J. (2001). "SW-soil and water: Lignin-based interpolymer complexes as a novel adhesive for protection against erosion of sandy soil," Journal of Agricultural Engineering Research 78(3), 309-316.

Shulga, G., Soloddovniks, P., Shakels, V., and Anisckevicha, O. (2005). "New semiinterpenetrating polymer networks incorporating soluble lignin," Proceedings of the 7th ILI Forum-Barcelona, International Lignin Institute, Lausanne, 159-162.

Sjöström, E. (1982). Wood Chemistry: Fundamentals and Applications, Academic Press, ISBN 0-12-647480-x. 223p.

Sun, R. C., Lawther, M., and Banks, W. B. (1998). "Isolation and characterization of organosolv lignins from wheat straw," Wood and Fiber Science 30(1), 56-63.

Sun, N., Rahman, M., Qin, Y., Maxim, M. L., Rodriguez, R. H., and Rogers, R. D., (2009). "Complete dissolution and partial delignification of wood in the ionic liquid 1-ethyl-3-methylimidazolium acetate," Green Chemistry 11(5), 646-655.

Svensson, S. (2008). "Minimizing sulphur content in kraft lignin,” Degree Project. Mälardalen University. 35p. available via: http://mdh.divaportal.org/smash/get/diva2:1676/FULLTEXT01

Tan, S. S. Y., MacFarlane, D. R., Upfal, J., Edye, L. A., Doherty, W. O. S., Patti, A. F., Pringle, J. M., and Scott, J. L. (2009). "Extraction of lignin from lignocellulose at atmospheric pressure using alkylbenzenesulfonate ionic liquid," Green Chemistry 11(3), 339-345. 
Tejado, A., Peňa, C., Labidi, J., Echevérria, J. M., and Mondragon, I. (2007). "Physicochemical characterization of lignins from different sources for use in phenolformaldehyde resin synthesis," Bioresource Technology 98(8), 1655-1663.

Toledano, A., García, A., Mondragon, I., and Labidi, J. (2010a). "Lignin separation and fractionation by ultrafiltration," Separation and Purification Technology 71(1), 3843.

Toledano A., Serrano L., Garcia A., Mondragon I., and Labidi J. (2010b). “Comparative study of lignin fractionation by ultrafiltration and selective precipitation," Chemical Engineering Journal 157(1), 93-99.

Turunen, M., Alvila, L., Pakkanen, T. T., and Rainio, J. (2003). "Modification of phenolformaldehyde resol resins by lignin, starch and urea," J. Appl. Polym. Sci. 88(2), 582588.

Ungureanu, E., Ungureanu, O., Capraru, A.-M., and Popa, V. I. (2009). “Chemical modification and characterization of straw lignin," Cellulose. Chem. Technol. 43(78), 263-269.

van Spronsen, J., Tavares Cardoso, M., Witkamp, G.-J., de Jong, W., and Kroon, M. C. (2011). "Separation and recovery of the constituents from lignocellulosic biomass by using ionic liquids and acetic acid as co-solvents for mild hydrolysis," Chemical Engineering and Processing: Process Intensification 50(2), 196-199.

Veverka, P. J., and Nichols, K. M. (1992). "On the source and chemical form of nitrogen in kraft black liquor,” IPST Technical Paper Series 449, 10 pp.

Wang, J. P., Chen, H.-S., Shi, R., Li, Q., Sun, Y.-H., Sederoff, R., and Chiang, V. (2010). "Unlocking biofuel industry through comprehending lignin biosynthesis," Poster, Available via: http:/www.ncsu.edu/grad/research/docs/wang-poster-2010.pdf

Wang, M., Leitch, M., and Xu, C. (2009). "Synthesis of phenol-formaldehyde resol resins using organosolv pine lignins," European Polymer Journal 45(12), 3380-3388.

Weng, J.-K., Li, X., Bonawitz, N., and Chapple, C. (2008). "Emerging strategies of lignin engineering and degradation for cellulosic biofuel production," Current Opinion in Biotechnology 19(2), 166-172.

Wormeyer, K., Ingram, T., Saake, B., Brunner, G., and Smirnova, I. (2011). “Comparison of different pretreatment methods for lignocellulosic materials. Part II: Influence of pretreatment on the properties of rye straw lignin," Bioresource Technology 102(8), 4157-4164.

Xu, F., Sun, J.-X., Sun, R. C., Fowler, P., and Baird, M. S. (2006). "Comparative study of organosolv lignins from wheat straw," Industrial Crops and Products 23(2), 180-193.

Yuan, Z., Cheng, S., Leitch, M., and Xu, C. (2010). "Hydrolytic degradation of alkaline lignin in hot-compressed water and ethanol," Bioresource Technology 101(23), 93089313.

Zhang, J., Deng, H., Lin, L., Sun, Y., Pan, C., and Liu, S. (2010). "Isolation and characterization of wheat straw lignin with a formic acid process," Bioresource Technology 101(7), 2311-2316.

Zhang, L.-M. and Yin, D.-Y. (2002). "Preparation of a new lignosulphonate-based thinner: Introduction of ferrous ions," Colloids Surf. A: Physicochemical and Engineering Aspects 210(1), 13-21. 
Zhang, Y. H. (2008). "Reviving the carbohydrate economy via multi-product lignocelluloses biorefineries," Journal of Industrial Microbiology and Biotechnology $35(3), 367-375$.

Zoumpoulakis, L., and Simitzis, J. (2001). "Ion-exchange resins from PF resin modified lignin," Polym. Int. 50 (3), 277-283.

Article submitted: April 14, 2011; Peer review completed: May 16, 2011; Revised version received and accepted: June 5, 2011; Published: June 7, 2011. 